\title{
A Review of Financial Distress Prediction Models: Logistic Regression and Multivariate Discriminant Analysis
}

\author{
Ehsan ul Hassan ${ }^{*}$ Zaemah Zainuddin and Sabariah Nordin \\ School of Economics, Finance and Banking, Universiti Utara Malaysia
}

\begin{abstract}
In corporate finance, the early prediction of financial distress is considered more important as another occurrence of business risks. The study presents a review of literature for early prediction of financial bankruptcy. It contributes to the formation of a systematic review of the literature regarding previous studies done in the field of bankruptcy. It addresses two most commonly used financial distress prediction models, i.e. multivariate discriminant analysis and logit. Models are discussed with their advantages and disadvantages. After methodological review, it seems that logit regression model (LRM) is more advantageous than multivariate discriminant analysis (MDA) for better prediction of financial bankruptcy. However, accurate prediction of bankruptcy is beneficial to improve the regulation of companies, to form policies for companies and to take any precautionary measures if any crisis is about to come in future.
\end{abstract}

Keywords: Financial Distress Prediction, Logistic Regression, Multivariate Discriminant Analysis, Bankruptcy

JEL Classification: G30, O16, G33

Paper Type: Research

\section{INTRODUCTION}

Financial distress has numerous definitions such as situations are failure, default, insolvency and bankruptcy (Geng, Bose \& Chen, 2015). Predicting bankruptcy is one of the crucial issues which have been widely studied in accounting and finance literature. Bankruptcy is a worldwide problem which can occur in both developing and developed economies. However, mostly it occurs in developing economies (Geng, Bose \& Chen, 2015). Some of the main reasons behind company failures that vary among various

* Corresponding author: E-mail: ehsanulhassan786@gmail.com, Tel: +60 1114282346 
countries are social, economic and political environments of countries, their accounting standards and differences in their capital structures (Argenti, 1976; Her \& Choe, 1999). Evidently, the vast empirical studies show that researchers are concerned in examining the prediction of bankruptcy for various countries of the world. For example, France (Micha, 1984), Malaysia (Bidin, 1988), Korea (Altman et al., 1995), Turkey (Ugurlu \& Aksoy, 2006), India (Bandyopadhyay, 2006), and Iran (Etemadi et al., 2009).

After extensive use of bankruptcy prediction models in western economies, researchers are now using the bankruptcy models in transitional economies countries such as Eastern and Central Europe (Mihalovic, 2016). Nevertheless, the use of this bankruptcy model in these countries may depend upon different considerations. For instance, the use of financial institutions' risk rating models in assessing the risk of applicants applying for debt, whether the companies have joined European Union structures, and lastly, private financial equity groups use bankruptcy prediction models for better assessment of companies' financial position and to identify better investment opportunities in the market.

Since the 1960s until now, various early warning systems have been developed which aid in providing a timely prediction of financial distress of companies. It is also possible to categorize the models into various groups. Agarwal and Taffler (2008) categorised these models into two main groups: (i) market-based models; (ii) accounting-based models. Applying market-based models in Slovakia is limited due to underdeveloped capital market. So accounting -based models are suggested in the process of developing a bankruptcy predicting models. However, the use of accounting-based models have various disadvantages, which are (i) the use of historical data that may or may not provide enough information in predicting future performances, (ii) firms management can manipulate accounting numbers, (iii) the historical cost concept and conservatism concept indicates that the true value of firms asset may vary from their book values included in financial statements, and (iv) accounting statements are prepared using the concept of going-concern. Despite these drawbacks, it is reported that accounting based models are equally crucial to market-based models (Mihalovic, 2016).

\section{LITERATURE REVIEW}

Despite the numerous definitions of bankruptcy and remarkable diversity in using various statistical methods, financial economists have become successful in developing various models of bankruptcy which help in categorising the firms into bankrupt and non-bankrupt. The initial set of accounting models had been developed by Beaver (1966) and Altman (1968) to examine the failure risk of a corporation. Beaver (1966) used univariate statistical analysis to predict business failure. The authors used a dichotomous assessment model for a simple t-test in a univariate framework. The sample used in the study was 79 companies from 38 different sectors (nonfailed and failed companies) financial ratios that were classified by industry and resources size in 1954 to 1964. The ratio of Cash flow/Total Debt was found as the best indicator of the bankruptcy of corporate in the study. Altman (1968) became the first to present an accounting-based model to estimate the probability of corporate failures. He used twenty-two financial ratios for 66 companies from the period of 1946 to 1965 and used multivariate discriminant analysis (MDA) later known as a zscore model to differentiate surviving and defaulting companies. The model showed its 94 percent accuracy for bankrupt companies and 97 percent for non-bankrupt companies. $\mathrm{He}$ also revealed that this percentage of model accuracy decreased with the increasing number of yearly observations before bankruptcy. After that, many z-score models were introduced by Altman et al. (1977) which is also called ZETA and Altman et al. (1995) in the context of firms in the emerging markets. After conducting studies in 22 countries, 
Altman and Narayanan (1997) gave their conclusion that accounting models based on financial ratios such as (logistic regression, MDA and probit models) play an active role in predicting failure risks.

Dekin (1972) conducted research afterwards in which he used multiple discriminant analysis for analysing the possibility of corporate failure prediction. MDA discovers a linear combination of different ratios which distinguishes between desired groups that should be classified. The study aimed to replicate the studies done previously (Beaver, 1966; Altman, 1968) using same ratios. As a sample, he took 32 bankrupt companies from the year 1964 to 1970. The sample included every form of the insolvent, bankrupt and liquidated firm. These bankrupt firms were matched with non-bankrupt firms by year, asset size and industry classification. The data collected was from up to five years before bankruptcy. Almost all variables used in the study contribute significantly to the function's discriminant ability. Results of the study concluded that the ability to predict failure was more than that in the fourth and fifth year before bankruptcy. The study concluded that the discriminant analysis could show accurate results of failure prediction up to three years before bankruptcy. Though this study contributed significantly to failure prediction theory, it should also be kept in mind that the sample taken for analysis was quite small.

Blum (1974) conducted a research in which he included 115 bankrupt and 115 nonbankrupt firms from 1954 to 1968. All these firms were matched by employees, Sales, industry and financial year. For failure prediction model he included discriminant analysis along with 12 variables. His study concluded that accurate classification rates are shown above 70 percent. Ohlson (1980) used conditional logit analysis for the first time to predict business failure. The authors used nine financial ratios for 105 bankrupt and 2058 nonbankrupt firms from the year 1970 to 1976 . The study concluded that logit regression is quite appropriate for predicting corporate failure.

Zavgren (1985) stated that in predicting bankruptcy, the conditional probability models for example logit and probit are more helpful because these models do not hold linearity assumptions necessarily. The sample included 45 bankrupt and 45 non-bankrupt companies from 1972 to 1978 . The findings of the study showed that the model was envisioned to differentiate between non-failed and failed firms with more than $90 \%$ precision. Begley, Ming and Watts (1996) examined the extent to which the failure prediction models of Altman and Ohlson misclassify firms using the data from the 1980s. Authors conducted a study on the data of 1980's to predict the financial distress of manufacturing companies listed on American Stock Exchange (AMEX) or over the counter market (NASDAQ) and New York Stock Exchange (NYSE) for the period of 1980-1989. They concluded that Ohlson's model is far better than Altman's model as it involves a lower combined error rate which shows a higher percentage of model accuracy. Lennox (1999) researched to predicting bankruptcy using a sample of 949 companies of UK from the year 1987 to 1994. He argued that if probit and logit model is well-specified, then it produces accurate results as compare to discriminant analysis (DA).

After the logit model, Shumway (2001) developed a dynamic logit or a hazard model for bankruptcy forecasting. This model included complex period data instead of single period data, and it also included the time-varying covariates for 300 bankrupt companies listed at NYSE and AMEX. In addition to this, he also included classic accounting data and the equity market for shaping his model. Furthermore, to forecast bankruptcy, he highlighted the usefulness of market-driven variables which were ignored in previous studies for example market size of firms, past stock returns and the standard deviation of stock returns. After that, the studies by Hillegeist, Keating, Cram and Lundstedt (2004), Chava and Jarrow (2004) and Beaver, McNichols and Rhie (2005) also used the approach of Shumway (2001). However, the model used by Shumway (2001) was the hazard model based on discrete time. In this model, the rate of hazard means the chances of a company 
that goes bankrupt in "t" survival time. So the probability of bankruptcy mostly changes with the change in time period. This change in the likelihood of the passage of time not only creates ways for analysts to exploit the observations but also it creates the bankruptcy likelihood to change as covariates of independent variables changes over time.

Jones and Hensher (2004) developed a mixed logit model for predicting bankruptcy. They used the data of 4980 non-bankrupt and 229 bankrupt companies listed on the Australian Stock Exchange (ASX) from the year 2001 to 2003. They argued that unlikely binary logit models and the multinomial logit models, the mixed logit model included the random parameters standard deviations and mean, and lastly addition of heterogeneity in the mean. Significant findings included that mixed logit model is superior to multinomial logit in out of sample forecasts. Canbas, Cabuk and Kilic (2005) created an integrated early warning system (IEWS), for predicting banks failures, which is the combination of for statistical methods that are discriminant analysis, principal component analysis, probit analysis and the logit analysis. As a sample, they took the data of 40 private banks of Turkey from the year 1994 to 2001 . Results of the study supported the implication of these four statistical techniques for failure prediction, and also these techniques can be used by other sectors for predicting failures.

In addition to this Nam and Jinn (2006) established the model for predicting bankruptcy by using logit method which is an estimation technique on the basis of maximum likelihood. As a sample, he used 40 companies from the nonfinancial sector belonging to different industries of Korea. The period selected was from 1997 to 1998, a recession period in Korea, driven by International Monetary Fund (IMF). For forecasting bankruptcy, the study used liquidity ratio, interest expense to sales ratio and the liquidity ratio. 80.4 percent and 73.9 percent were Type I and Type II accuracy of failure prediction model. The model concluded that temporarily prevailing financial crisis in Korea is not the only reason for the increased rate of bankruptcy but the poor performance of companies over an extended period was also a major reason.

Campbell, Hilscher and Szilagyi (2008) argued that the firms which take high risks related to business failures mostly show low returns on stocks. They conducted a study using observations of every month from the year 1963 to 1998 . However, for analysis, they used failure indicators from the year 2003. As a sample, they took all bankrupt firms reported in SDC database, Wall Street Journal Index, SEC filings and CCH Capital Changes Reporter. For dynamic logit model, both accounting and market variables were taken. The study concluded that the stocks belonging to high default risk yielded low stock returns. Another study was conducted in Malaysia by Abdullah, Halim, Ahmad and Rus (2008). They conducted a comparative study by examining bankrupt companies of Malaysia. The comparative study was done on MDA, logistic regression and the hazard model. As a sample, they took the data of 52 non-bankrupt and bankrupt firms. Among the three models, the holdout sample of 20 firms showed that the hazard model had the most exceptional accuracy in bankruptcy prediction of 94.9 percent. After that, the second most accurate model is MDA which has the accuracy level of 85 percent.

For Bankruptcy prediction, Li, Lee, Zhou, and Sun (2011) researched by generating the RSB-L model by combining random subspace approach (RSB) and binary logit model $(L)$ which takes into account the decision agent's opinions for bringing improvement in the performance of logit model. The study focused on the usefulness of the likelihood of default implied by equity and the treatment of primary variables as compared to the predictive information competing for sources. The study concluded that instead of classical statistical models, the RSB-L model could be applied for predicting bankruptcy. They also concluded that the Fisher discriminant analysis is fundamental in testing the feasibility and effectiveness of dynamic modelling for bankruptcy prediction. For various occurrence choices such as they developed a system of dynamic bankruptcy prediction as full memory 
window, window with a fixed size, no memory window, batch selection and window with adaptable size. They used starting elements set which were made of seven parts financial ratios by suggesting a wrapper which integrates forward and backward selection. The results indicate that the dynamic models are useful for further classification techniques as this model showed better results instead of statistical models.

In addition to this, another study was conducted by Bhunia and Sarkar (2011) to improve further the ability to predict. Predictive models are thought to be very important for companies having different financial structure and management in India's context. As a sample, they took the data of private companies of manufacturing sector from the year 1996 to 2005. Financial reports of companies five years before bankruptcy were collected, and then 32 failed, and 32 nonfailed companies were selected. For peer match samples of both failed and non-failed companies were taken. Seven ratios with discriminant function were considered to be useful in the classification and discrimination expressing 88 percent and 94 percent of predicting ability. The study concluded that MDA is the best model for predicting bankruptcy as it has a high level of accuracy.

Chen (2011) carried out research to improve the accuracy of failure prediction model by collecting data of 100 listed companies of Taiwan Stock Exchange Corporation (TSEC) as the initial sample. In empirical research, the author used 37 ratios which include both financial and non-financial ratios from 2000 to 2007. The authors used principal component analysis to find the suitable variables. Other methods included in the prediction model for financial distress is logistic regression technique and decision tree. This research gave fruitful result and also verified the validity and possibility of the proposed method for predicting financial failures of the listed companies. The study concluded that decision tree (DT) approach is better in short run prediction of financial distress.

Sarlija (2009) conducted research using decision trees, logistic regression and neural networks for bankruptcy prediction. As a sample, he took 200 loan applications out of which 133 remained good loan decisions afterwards while 67 defaulted. The data was collected from a Croatian credit deposit company. The following characteristics of the company were used for prediction: lending institution-entrepreneur relationship, business idea, credit program characteristics, growth plan, business characteristics, marketing plan and the entrepreneur characteristics. The results showed that the most accurate predictor for predicting credit default is the logistic regression which had $83 \%$ accuracy for correct classification. While other models had less predictive ability as ANNs had accuracy from $44 \%$ to $69 \%$ and DTs had $44 \%$ to $79 \%$ accuracy.

Rashid \& Abbas (2011) conducted a study in Pakistan but limited to only two sectors, i.e. textile and sugar sector for assessing the financial soundness using various financial ratios. Authors used 24 financial ratios for 52 non-financial companies for the period of 1996 to 2006 and concluded that the most significant financial ratios to predict firm's bankruptcy in Pakistan are earnings before interest and taxes to current liabilities, cash flow ratio and sales to total assets ratio. Model of the study secured 76.9 percent of accuracy level for bankruptcy prediction.

Table 2.1. Summary of financial distress literature

\begin{tabular}{|c|c|c|c|}
\hline Authors & Country & Method & Major Findings \\
\hline $\begin{array}{l}\text { Beaver } \\
(1966)\end{array}$ & USA & $\begin{array}{l}\text { A used sample of } 79 \text { companies from } \\
38 \text { different sectors from } 1954 \text { to } \\
1964 \text {, univariate statistical analysis }\end{array}$ & $\begin{array}{l}\text { The ratio of Cash flow/Total Debt } \\
\text { was found the best predictor for } \\
\text { bankruptcy; differences exist } \\
\text { between the financial ratios of five } \\
\text { years before the bankruptcy }\end{array}$ \\
\hline $\begin{array}{l}\text { Altman } \\
\text { (1968) }\end{array}$ & USA & $\begin{array}{l}\text { Used } 22 \text { financial ratios for } 66 \\
\text { companies from the period of } 1946 \\
\text { to } 1964 \text {, multivariate discriminant } \\
\text { analysis (MDA) }\end{array}$ & $\begin{array}{l}\text { The model showed } 94 \text { percent } \\
\text { accuracy for bankrupt companies } \\
\text { and } 97 \text { percent for non-bankrupt } \\
\text { companies. Also revealed that }\end{array}$ \\
\hline
\end{tabular}




\begin{tabular}{|c|c|c|c|}
\hline Authors & Country & Method & Major Findings \\
\hline & & & $\begin{array}{l}\text { percentage of model accuracy } \\
\text { decreases with the increase of yearly } \\
\text { observations before bankruptcy }\end{array}$ \\
\hline $\begin{array}{l}\text { Altman et al. } \\
(1977)\end{array}$ & USA & $\begin{array}{l}\text { Used } 27 \text { financial ratios for } 111 \\
\text { companies from the period of } 1969 \\
\text { to } 1975 \text {, ZETA model }\end{array}$ & $\begin{array}{l}\text { Reported } 90 \text { percent of accuracy } \\
\text { rate for one-year prior bankruptcy } \\
\text { and more than } 70 \text { percent accuracy } \\
\text { for five years }\end{array}$ \\
\hline $\begin{array}{l}\text { Ohlson } \\
(1980)\end{array}$ & USA & $\begin{array}{l}\text { Used nine financial ratios for } 105 \\
\text { bankrupt and } 2058 \text { non-bankrupt } \\
\text { companies from the period of } 1970 \\
\text { to } 1976 \text {, logit model }\end{array}$ & $\begin{array}{l}\text { The study showed significant results } \\
\text { with } 93 \text { percent accuracy level and } \\
\text { revealed that predictive ability of any } \\
\text { model depends upon the extent to } \\
\text { which information is available }\end{array}$ \\
\hline $\begin{array}{l}\text { Zavgren } \\
(1985)\end{array}$ & USA & $\begin{array}{l}\text { The sample included } 45 \text { bankrupt } \\
\text { and } 45 \text { non-bankrupt companies } \\
\text { from } 1972 \text { to } 1978 \text {, logit model }\end{array}$ & $\begin{array}{l}\text { Model classified bankrupt and non- } \\
\text { bankrupt companies with } 90 \text { percent } \\
\text { of accuracy level. }\end{array}$ \\
\hline $\begin{array}{l}\text { Begley, Ming } \\
\text { and Watts } \\
(1996)\end{array}$ & USA & $\begin{array}{l}\text { Used listed manufacturing } \\
\text { companies in AMEX, NASDAQ and } \\
\text { NYSE from } 1980 \text { to 1989, MDA and } \\
\text { logit }\end{array}$ & $\begin{array}{l}\text { Concluded that Ohlson's (logit) } \\
\text { model is better than Altman's model } \\
\text { with lower combined error rate and a } \\
\text { higher percentage of model } \\
\text { accuracy. }\end{array}$ \\
\hline $\begin{array}{l}\text { Shumway } \\
\text { (2001) }\end{array}$ & USA & $\begin{array}{l}\text { Included multiple period data instead } \\
\text { of a single period of } 300 \text { companies } \\
\text { from } 1962 \text { to } 1992 \text {, market-driven } \\
\text { variables were used, dynamic logit or } \\
\text { a hazard model }\end{array}$ & $\begin{array}{l}\text { Market-driven variables are } \\
\text { important for prediction of financial } \\
\text { bankruptcy. The model showed } \\
\text { theoretically preference over static } \\
\text { models. }\end{array}$ \\
\hline $\begin{array}{l}\text { Jones and } \\
\text { Hensher } \\
(2004)\end{array}$ & Australia & $\begin{array}{l}\text { Used } 4980 \text { non-bankrupt and } 229 \\
\text { bankrupt companies listed on the } \\
\text { Australian Stock Exchange (ASX) } \\
\text { from the year } 2001 \text { to 2003, mixed } \\
\text { logit model }\end{array}$ & $\begin{array}{l}\text { Major findings included that mixed } \\
\text { logit model is superior to multinomial } \\
\text { logit in out of sample forecasts. }\end{array}$ \\
\hline $\begin{array}{l}\text { Canbas, } \\
\text { Cabuk and } \\
\text { Kilic }(2005)\end{array}$ & Turkey & $\begin{array}{l}\text { Included } 40 \text { private banks of Turkey } \\
\text { from the year } 1994 \text { to } 2001 \text {, used } \\
\text { discriminant analysis, principal } \\
\text { component analysis, probit analysis } \\
\text { and logit analysis. }\end{array}$ & $\begin{array}{l}\text { PCA was successfully combined } \\
\text { with other three models and declared } \\
\text { as a successful tool for the prediction } \\
\text { of financial failure in Turkish banking } \\
\text { industry }\end{array}$ \\
\hline $\begin{array}{l}\text { Nam and } \\
\text { Jinn (2006) }\end{array}$ & Korea & $\begin{array}{l}40 \text { manufacturing companies from } \\
1997 \text { to } 1998 \text {. Logit analysis }\end{array}$ & $\begin{array}{l}\text { Results reported } 80.4 \text { percent and } \\
73.9 \text { percent accuracy level for Type } \\
\text { I and Type II error of the model }\end{array}$ \\
\hline $\begin{array}{l}\text { Abdullah, } \\
\text { Halim, } \\
\text { Ahmad and } \\
\text { Rus (2008) }\end{array}$ & Malaysia & $\begin{array}{l}52 \text { companies were used for hazard } \\
\text { model, MDA and logit analysis }\end{array}$ & $\begin{array}{l}\text { Hazard model outperforms with } 94.9 \\
\text { percent of model accuracy level }\end{array}$ \\
\hline $\begin{array}{l}\text { Li, Lee, } \\
\text { Zhou, and } \\
\text { Sun (2011) }\end{array}$ & China & $\begin{array}{l}\text { Used } 30 \text { financial ratios for } 135 \text { pair } \\
\text { of companies from Shanghai Stock } \\
\text { Exchange and the Shenzhen Stock } \\
\text { Exchange, applied random } \\
\text { subspace binary logit (RSBL), model }\end{array}$ & $\begin{array}{l}\text { Instead of classical statistical } \\
\text { models, the RSB-L model can be } \\
\text { applied as dynamic models could be } \\
\text { useful for classification techniques } \\
\text { with better results }\end{array}$ \\
\hline $\begin{array}{l}\text { Bhunia and } \\
\text { Sarkar } \\
(2011)\end{array}$ & India & $\begin{array}{l}16 \text { financial ratios were used for } 64 \\
\text { private pharmaceutical companies } \\
\text { from } 1996 \text { to } 2005, \text { MDA }\end{array}$ & $\begin{array}{l}\text { Results showed the high predictive } \\
\text { power of the model in case of } \\
\text { pharmaceutical sector of India. }\end{array}$ \\
\hline Chen (2011) & Taiwan & $\begin{array}{l}37 \text { financial ratios were used for } 100 \\
\text { listed companies at Taiwan stock } \\
\text { exchange from } 2000 \text { to 2007, } \\
\text { Decision trees and logit model }\end{array}$ & $\begin{array}{l}\text { Decision tree approach is better in } \\
\text { short run prediction of financial } \\
\text { distress. }\end{array}$ \\
\hline Blum (1974) & USA & $\begin{array}{l}115 \text { bankrupt and } 115 \text { non-bankrupt } \\
\text { companies included for a period of } \\
1954-1968 \text { with } 12 \text { financial ratios in } \\
\text { the analysis, MDA }\end{array}$ & $\begin{array}{l}\text { Model classified bankrupt and non- } \\
\text { bankrupt companies with } 70 \text { percent } \\
\text { of accuracy level. }\end{array}$ \\
\hline $\begin{array}{l}\text { Lennox } \\
\text { (1999) }\end{array}$ & $\begin{array}{l}\text { United } \\
\text { Kingdom }\end{array}$ & $\begin{array}{l}949 \text { companies used with a sample } \\
\text { period of the year } 1987 \text { to } 1994 \text {, logit, } \\
\text { probit and discriminant analysis }\end{array}$ & $\begin{array}{l}\text { The author concluded that if probit } \\
\text { and logit model is well-specified, }\end{array}$ \\
\hline
\end{tabular}




\begin{tabular}{|c|c|c|c|}
\hline Authors & Country & Method & Major Findings \\
\hline & & & $\begin{array}{l}\text { then it produces accurate results as } \\
\text { compare to discriminant analysis. }\end{array}$ \\
\hline $\begin{array}{l}\text { Sarlija } \\
\text { (2009) }\end{array}$ & Croatia & $\begin{array}{l}200 \text { loan applications from Croatian } \\
\text { credit deposit company, decision } \\
\text { trees, logistic regression and neural } \\
\text { networks }\end{array}$ & $\begin{array}{l}\text { Logistic regression model had the } \\
\text { highest accuracy level of prediction } \\
\text { with } 83 \text { percent, which is higher than } \\
\text { other models used in the analysis }\end{array}$ \\
\hline $\begin{array}{l}\text { Rashid and } \\
\text { Abbas } \\
(2011)\end{array}$ & Pakistan & $\begin{array}{l}\text { Used } 24 \text { financial ratios for } 52 \text { non- } \\
\text { financial companies from the period } \\
\text { of } 1996 \text { to } 2006 \text {, MDA }\end{array}$ & $\begin{array}{l}\text { Model secured } 76.9 \text { percent of } \\
\text { accuracy level for bankruptcy } \\
\text { prediction }\end{array}$ \\
\hline
\end{tabular}

Table 1 summarises the past studies, which have been done for predicting financial distress. It also depicts the techniques and models used by previous researchers. Country names are also shared to notice that the review of literature is done globally. In the last major findings of the studies are illustrated for each study respectively.

\section{REVIEW OF PREDICTION MODELS}

Commonly, two statistical analysis techniques have frequently been used in empirical studies for classification of companies. These techniques are MDA and logistic regression. Detail of these techniques and their advantages and disadvantages are discussed in Sections 3.1 to 3.2 .

\subsection{Multivariate Discriminant Analysis}

Multiple discriminant analysis is statistical that is used for classification of observation into one of various theoretically derived groups which are dependent on the individual characteristics of that observation. One of the primary objectives of MDA is to categorise and predict the problems in cases where the dependent variable is of qualitative nature such as bankrupt and non-bankrupt, female-male amongst others.

The main concern of researchers in bankruptcy prediction models is non-bankrupt firms and the bankrupt firms. So the analysis in such case is moulded in one direction. If there are g groups then the discriminant function for a group i will be shown as:

$$
d i=W_{i 1} X_{1}+W_{i 2} X_{2}+W_{i 3} X_{3}+\ldots . .+W_{i n} X_{n}
$$

in the above equation

$\mathrm{i}=1 \ldots . \mathrm{g}$

$\mathrm{w}_{\mathrm{ij}}$ denotes the discriminant coefficients,

ci is a constant term, and

$\mathrm{xj}$ is discriminant variable

The multivariate discriminant analysis is challenging to apply because of its statistical shortcomings (Eisenbeis, 1977). Those shortcomings are described by explaining the limitations that diminish the explanatory power of the model (Premachandra et al., 2009). The limitations are described as follows. First, the preceding likelihood of distress and misclassification costs are indicated. Second, the ratios used in the MDA are normally distributed. Third, the proclivity of equal variance-covariance matrices across groups. Zavgren (1985) have questioned the generalities and inferences derived from MDA because of disruption of axioms. 
The recent research is focused on overcoming the limitations prevailing in frequently used statistical techniques. Therefore, other statistical models came into attention which is conditional probability models, i.e. logistic regression or probit. The pioneering work in the prediction of bankruptcy is done by Ohlson (1980) who used the logit model in his research. Laitinen, Lukason and Suvas (2014) described that logit model is more effective and practical than MDA because it does not have assumptions of uniform covariance matrices and multivariate normality. Additionally, MDA implicated non-linear effects, empowering the use of a logistical cumulative function for prediction of inhibiting bankruptcy.

Furthermore, Aziz and Dar (2006) expressed comprehensively that in the area of prediction of bankruptcy, the most significant solutions are MDA and logistic regression, which will frequently be used in the future empirical studies. Ohlson (1980) have used logistic regression to predict the bankruptcy of firms. The same methodology is being used in different empirical studies such as Chen (2011), Zavgren (1985).

\subsection{Logistic Regression}

Logistic regression is a suitable technique for financial distress prediction if the dependent variable is categorical while independent variables (Hair et al., 1998). Additionally, the frequent use of logistic regression is because of two reasons, that is, it consists of nonlinear relationship, and secondly, it is not necessary to meet the statistical assumptions like in linear regression relationships. Logistic regression and MDA are parallel if MDA assumptions are held (Kolari et al., 2002).

The logit model is based on cumulative logistic function. That is why the probability of firm belonging to a prior group is obtained to analyse the financial position. The probability of going to bankruptcy is computed as follows:

where

$$
P_{L_{a}}=\frac{1}{1+e^{-\left(Z_{L_{a}}\right)}}
$$

$$
Z_{L_{a}}=\beta_{1} \chi_{1 a}+\beta_{2} \chi_{2 a}+\cdots+\beta_{n} \chi_{n a}
$$

Logistic regression is advantageous when the prediction is based on the values of independent variables. Logistic regression is a non-linear regression which is specified to the dichotomous dependent variable. Logistic regression is specified to determine the odds ratios for each explanatory variable used in the model. This regression assists in forming the multivariate regression between dependent and independent variables (Lee, Ryu \& Kim, 2007). The result of this regression determines the probability of occurrence of two responses ( 0 and 1$)$ or (yes or no) depending upon the definition of two values of the response variable (Tabachnick \& Fidell, 2001).

Logistic regression permits to predict a precise outcome, like membership of the group, from variables which can be dichotomous, continuous, or discrete, or a mixture of all these. Usually, the response variable is categorical: as absence/presence or failure/success. In cases where the explanatory variables are categorical, a mix of categorical and continuous, logistic regression is favoured (Dutta, Bandopadhyay, \& Sengupta, 2015). 
Table 3.1. Comparison of MDA and logit model

\begin{tabular}{|c|c|c|}
\hline Model & Advantages & Disadvantages \\
\hline \multirow[t]{9}{*}{ MDA model } & 1. Multivariate model & 1. Follows Linearity assumption \\
\hline & 2. Continuous scoring model & 2. Assumes dichotomous dependent \\
\hline & & 3. Three restrictive assumptions \\
\hline & & (multivariate normality; misclassification \\
\hline & & $\begin{array}{l}\text { costs; prior } \\
\text { probabilities) }\end{array}$ \\
\hline & & 4. Classification model (not specifically a \\
\hline & & prediction model) only gives ordinal scores \\
\hline & & $\begin{array}{l}5 \text {. The relative importance of ratios is } \\
\text { unidentified }\end{array}$ \\
\hline & & 6. Not opposed to severe multicollinearity \\
\hline \multirow[t]{11}{*}{ Logit model } & 1. Multivariate model & 1. The assumption on the probability \\
\hline & 2. Continuous scoring model & distribution \\
\hline & 3. No distributional assumptions for & 2. The assumption on dichotomous \\
\hline & independent variables - & dependent variable \\
\hline & 4. Allows Qualitative variables & 3. Extremely sensitive to multi-collinearity \\
\hline & 5. No linearity assumption & 5. Sensitive to extreme non-normality of \\
\hline & 6. No requirement of Prior probabilities & independent variables \\
\hline & $\begin{array}{l}\text { 7. The relative significance of ratios is } \\
\text { identified }\end{array}$ & 6. Sensitive to outliers and missing values \\
\hline & $\begin{array}{l}\text { 8. Assumes that errors are sketched from a } \\
\text { binomial distribution }\end{array}$ & \\
\hline & 9. Preferred in the instance when IVs are & \\
\hline & $\begin{array}{l}\text { categorical or mix of categorical and } \\
\text { continuous variables }\end{array}$ & \\
\hline
\end{tabular}

Table 2 summarises the advantages and disadvantages of the use of MDA and logit model which differentiate these two models. Logit model seems to be more advantageous than MDA due to its welcoming attribute towards financial data.

\section{CONCLUDING REMARKS}

This paper contributes to a systematic review of literature of financial distress prediction models. The review shows a comprehensive view of previous studies in detail in tabulated form. It also generates a discussion on most frequently used bankruptcy prediction models (i.e., MDA and logit models). Both models are discussed and differentiated on the basis of their core advantages and disadvantages. After reviewing methodological literature logit model is suggested to use for the prediction of financial bankruptcy. Conclusively, early prediction models of financial distress are beneficial for financial regulators because they can use this tool to analyse the companies they are regulating. Policymakers can also take benefit from this tool as they are the key to financial system prevailing in the markets. They can use this tool to analyse the financial decisions of firms and its consequences. On the basis of this information, they can form effective policies on time and for future to avoid any crisis. Overall, this tool is beneficial to improve the regulation of companies, form policies for companies and to take precautionary measures if any crisis is about to come in future.

\section{REFERENCES}

Abdullah, N. A. H., Halim, A., Ahmad, H., \& Rus, R. M. (2008). Predicting corporate failure of Malaysia's listed companies: Comparing multiple discriminant analysis, logistic regression and the hazard model. International Research Journal of Finance and Economics, 15, 201-217. 
Agarwal, V., \& Taffler, R. (2008). Comparing the performance of market-based and accountingbased bankruptcy prediction models. Journal of Banking \& Finance, 32(8), 1541-1551.

Altman, E. I. (1968). Financial ratios, discriminant analysis and the prediction of corporate bankruptcy. The Journal of Finance, 23(4), 589-609.

Altman, E. I., \& Narayanan, P. (1997). An international survey of business failure classification models. Financial Markets, Institutions \& Instruments, 6(2), 1-57.

Altman, E. I., Eom, Y. H., \& Kim, D. W. (1995). Failure prediction: evidence from Korea. Journal of International Financial Management \& Accounting, 6(3), 230-249.

Altman, E. I., Haldeman, R. G., \& Narayanan, P. (1977). Zeta TM analysis a new model to identify bankruptcy risk of corporations. Journal of Banking \& Finance, 1(1), 29-54.

Argenti, J. (1976). Corporate collapse: the causes and symptoms. McGraw-Hill London.

Aziz, A. M., \& Dar, H. A. (2006). Predicting corporate bankruptcy: where we stand?. Corporate Governance: The international journal of business in society, 6(1), 18-33.

Bandyopadhyay, A. (2006). Predicting probability of default of Indian corporate bonds: logistic and Z-score model approaches. The Journal of Risk Finance, 7(3), 255-272.

Beaver, W. H. (1966). Financial ratios as predictors of failure. Journal of accounting research, 4(1), 71-111.

Beaver, W. H., McNichols, M. F., \& Rhie, J. (2005). Have financial statements become less informative? Evidence from the ability of financial ratios to predict bankruptcy. Review of Accounting Studies, 10(1), 93-122.

Begley, J., Ming, J., \& Watts, S. (1996). Bankruptcy classification errors in the 1980s: An empirical analysis of Altman's and Ohlson's models. Review of Accounting Studies, 1(4), 267-284.

Bhunia, A., \& Sarkar, R. (2011). A study of financial distress based on MDA. Journal of Management Research, 3(2), 1.

Bidin, A. R. (1988). The development of a predictive model (PNBScore) for evaluating the performance of companies owned by the government of Malaysia. Studies in Banking \& Finance, 7, 91-103.

Blum, M. P. (1974). Failing Company Discriminant Analysis, Journal of Accounting Research,12 (1): $1-25$.

Campbell, J. Y., Hilscher, J., \& Szilagyi, J. (2008). In search of distress risk. The Journal of Finance, 63(6), 2899-2939.

Canbas, S., Cabuk, A., \& Kilic, S. B. (2005). Prediction of commercial bank failure via multivariate statistical analysis of financial structures: The Turkish case. European Journal of Operational Research, 166(2), 528-546.

Chava, S., \& Jarrow, R. A. (2004). Bankruptcy prediction with industry effects. Review of Finance, $8(4), 537-569$.

Chen, M. Y. (2011). Predicting corporate financial distress based on integration of decision tree classification and logistic regression. Expert Systems with Applications, 38(9), 11261-11272.

Deakin, E. B. (1972). A discriminant analysis of predictors of business failure. Journal of Accounting Research, 10 (1), 167-179.

Dutta, A., Bandopadhyay, G., \& Sengupta, S. (2015). Prediction of stock performance in Indian stock market using logistic regression. International Journal of Business and Information, 7(1), 105-134.

Eisenbeis, R. A. (1977). Pitfalls in the application of discriminant analysis in business, finance, and economics. The Journal of Finance, 32(3), 875-900.

Etemadi, H., Rostamy, A. A. A., \& Dehkordi, H. F. (2009). A genetic programming model for bankruptcy prediction: Empirical evidence from Iran. Expert Systems with Applications, 36(2), 3199-3207.

Geng, R., Bose, I., \& Chen, X. (2015). Prediction of financial distress: An empirical study of listed Chinese companies using data mining. European Journal of Operational Research, 241(1), 236-247.

Hair, J. F., Black, W. C., Babin, B. J., Anderson, R. E., \& Tatham, R. L. (1998). Multivariate data analysis. Uppersaddle River. Multivariate Data Analysis (5th ed) Upper Saddle River.

Her, Y. W., \& Choe, C. (1999). A comparative study of Australian and Korean accounting data in business failure prediction models. Melbourne: La Trobe University. 
Hillegeist, S. A., Keating, E. K., Cram, D. P., \&Lundstedt, K. G. (2004). Assessing the probability of bankruptcy. Review of Accounting Studies, 9(1), 5-34.

Jones, S., \& Hensher, D. A. (2004). Predicting firm financial distress: A mixed logit model. The Accounting Review, 79(4), 1011-1038.

Kolari, J., Glennon, D., Shin, H., \& Caputo, M. (2002). Predicting large US commercial bank failures. Journal of Economics and Business, 54(4), 361-387.

Laitinen, E. K., Lukason, O., \& Suvas, A. (2014). Behaviour of financial ratios in firm failure process: an international comparison. International journal of finance and accounting, 3(2), 122-131.

Lee, S., Ryu, J. H., \& Kim, I. S. (2007). Landslide susceptibility analysis and its verification using likelihood ratio, logistic regression, and artificial neural network models: a case study of Youngin, Korea. Landslides, 4(4), 327-338.

Lennox, C. (1999). Identifying failing companies: a re-evaluation of the logit, probit and DA approaches. Journal of Economics and Business, 51(4), 347-364.

Li, H., Lee, Y., Zhou, Y., \& Sun, J. (2011). The random subspace binary logit (RSBL) model for bankruptcy prediction. Knowledge-Based Systems, 24(8), 1380-1388.

Micha, B. (1984). Analysis of business failures in France. Journal of Banking \& Finance, 8(2), 281 291.

Mihalovic, M. (2016). Performance comparison of multiple discriminant analysis and logit models in bankruptcy prediction. Economics \& Sociology, 9(4), 101.

Nam, J. H., \& Jinn, T. (2000). Bankruptcy prediction: Evidence from Korean listed companies during the IMF crisis. Journal of International Financial Management \& Accounting, 11(3), 178-197.

Ohlson, J. A. (1980). Financial ratios and the probabilistic prediction of bankruptcy. Journal of accounting research, 18(1), 109-131.

Premachandra, I. M., Bhabra, G. S., \& Sueyoshi, T. (2009). DEA as a tool for bankruptcy assessment: A comparative study with logistic regression technique. European Journal of Operational Research, 193(2), 412-424.

Rashid, A., \& Abbas, Q. (2011). Predicting Bankruptcy in Pakistan. Theoretical and Applied Economics, 18(9), 103-128.

Sarlija, N., Penavin, S., \& Harc, M. (2009). Forecasting enterprise illiquidity in Croatia. Zbornik Ekonomskog fakulteta u Zagrebu, 7(2), 21-36.

Shumway, T. (2001). Forecasting bankruptcy more accurately: A simple hazard model. The Journal of Business, 74(1), 101-124.

Tabachnick, B. G. \& Fidell, LS (2001). Using multivariate statistics. Boston: Allyn and Bacon. Bamberger et, 31, I.

Ugurlu, M., \& Aksoy, H. (2006). Prediction of corporate financial distress in an emerging market: the case of Turkey. Cross-Cultural Management: An International Journal, 13(4), 277-295.

Zavgren, C. V. (1985). Assessing the vulnerability to failure of American industrial firms: a logistic analysis. Journal of Business Finance \& Accounting, 12(1), 19-45. 